\title{
Applications and applicability of Social Cognitive Theory in Information Science Research
}

\author{
Lyndsey Jenkins, Hazel Hall, Robert Raeside \\ Edinburgh Napier University, Edinburgh, UK
}

\begin{abstract}
Social Cognitive Theory (SCT) is a theory that derives from Psychology, yet has been adopted in other interdisciplinary subject areas, including Information Science. The origins and key concepts of SCT are presented, and the value of SCT's contributions to Information Science research analysed, with particular reference to research into information seeking behaviour and use and knowledge sharing. Prior applications of SCT in Information Science research are related to a study of employee-led workplace learning and innovative work behaviour that has been designed to create new insight on (i) workplace information literacy; (ii) knowledge management; and (iii) the relationship between information behaviours and innovation processes. It is anticipated that this research will also extend understandings of SCT as a valuable tool for theory development across a range of domains that focus on learning processes.
\end{abstract}

\section{Keywords}

information literacy, information seeking behaviour and use, innovative work behaviour, Social Cognitive Theory, workplace learning

\section{Introduction}

Interdisciplinary domains, such as Information Science, often borrow theory from elsewhere (Hall, 2003). This allows for the analysis, synthesis and harmonisation of links between disciplines into a coordinated and coherent whole. Multidisciplinary approaches that involve researchers from different disciplines working together, each drawing on their own disciplinary knowledge, can also be accommodated in such practice.

This borrowing of theory can be observed in the research literature of a range of disciplines, including Information Systems (Treux, Holström and Keil, 2006), Nursing (Rijsford, 2009) and Organisational Studies (Whetten, Felin and King, 2009, p. 538). In the case of Information Science, with its strong interests in behaviours associated with information use, the application of theory that originates from Psychology is not uncommon.

Discussed in this paper is one such psychological theory: Social Cognitive Theory (SCT). An account of the origin and key concepts of SCT is given, illustrated with examples from the broad range of subject domains to which it contributes. Thereafter a detailed analysis of SCT's contribution to Information Science research is presented.

The practical value of SCT is then considered with reference to a study funded by UK Economic and Social Research Council and Skills Development Scotland in 2015. This research explores employee-led workplace learning and innovative work behaviour i.e. the set of behaviours that relate to the intentional generation of new ideas within a role, group or organisation (Battistelli, Montani and Odardi, 2013:27), as viewed through the disciplinary lens of Information Science, with the goal of devising a framework that explains how workplace learning can support innovative work behaviour development within organisations.

\section{Social Cognitive Theory: origins and key concepts}

In broad terms, SCT is a psychologically derived theory that explains how individuals within social systems enact multiple human processes, including the acquisition and adoption of information and knowledge. Its main focus is processes of learning, and the interplay between multiple factors therein. Developed by Bandura from the mid1970s onwards (Bandura, 1977; 1986; 1988; 1989; 1998; $2000 ; 2001 ; 2004 ; 2009)$, SCT has been widely deployed in research across a range of disciplines, as will be illustrated below.

SCT's roots can be traced to the 1940 s and articulations of Social Learning and Imitation Theory (Pálsdóttir, 2013). The main tenet of Social Learning and Imitation Theory is that individuals are prompted to learn in response to various drivers, cues, responses, and rewards, one of which is social motivation. A more recent, and direct, antecedent of SCT is Social Learning Theory (Bandura, 1997). Social Learning Theory explains that people learn through the social processes of observing, imitating, and modelling the behaviours of others. Bandura (1986)

\section{Corresponding Author:}

Lyndsey Jenkins, School of Computing, Edinburgh Napier University, 10 Colinton Road, Edinburgh EH10 5DT, UK

Email: I.jenkins@napier.ac.uk 
adapted Social Learning Theory as SCT to encompass determinants of learning that are neglected in its predecessor: cognitive elements important to the learning process, such as thought (for example, anticipated outcome expectations) and feelings (for example, anxiety), are also considered.

Interactions between social and cognitive factors of learning as determinants of behaviour are thus a distinctive feature of SCT (Pálsdóttir, 2013). This is known as 'reciprocal determinism' (Bandura, 1971). A causal model labelled 'triadic reciprocal causation' highlights the three sets of factors that interplay, interact, and bear influence. These are (i) cognitive and other personal factors such as values, goals and beliefs; (ii) environmental factors; and (iii) behavioural factors. Personal factors, for example, determine how individuals model and reinforce actions observed in other others. This in turn, determines the behaviours that individuals exhibit in the situation of learning.

SCT also recognises the value of agency. Here individual human agency is two-fold: individuals are considered dependent agents that are both products of the social system in which they live, as well as determinants of that system's production. They have individual agency to perform independently in any given environment, as well as collective agency when they rely on others to achieve performance collectively through group efforts (Bandura, 2000). Wider networks within social systems are also important in SCT because they provide pathways for the distribution of behaviours across populations.

Learning is the social process that represents the primary focus of SCT. SCT suggests that such acquisition of knowledge and skills comes through 'enactive mastery experience', i.e. direct experience of skills or tasks, and 'mastery modelling', i.e. observational learning from role models (Gong, Huang and Farh, 2009: 767). In SCT the mastery of new skills and knowledge are of greater interest than the outcome or objective of the learning process.

Self-efficacy, i.e. the personal belief that a task or goal can be successfully achieved within a particular setting, is a concept in SCT that merits particular attention, especially with reference to learning and skills development. Bandura introduced this concept to (the then developing) SCT in 1977 to acknowledge cognitive mediation of action that motivates and enables the processing of stimuli for the alteration of behaviours and actions (Pálsdóttir, 2013). As well as contributing to the effectiveness with which a behaviour can be mastered, self-efficacy also influences the application of skills, and whether or not these are put to good use (Bandura, 1998). The four main sources of self-efficacy are summarised in Table 1.

Table 1: Sources of self-efficacy (Bandura, 1998)

\begin{tabular}{|l|l|}
\hline Source & Description \\
\hline Mastery of experience & $\begin{array}{l}\text { The successful completion of prior tasks builds confidence to face } \\
\text { future problems and overcome them }\end{array}$ \\
\hline Vicarious experience & $\begin{array}{l}\text { Observations of peer success encourages positive judgements of } \\
\text { individual performance in similar situations }\end{array}$ \\
\hline Social persuasion & Encouragement from other to perform successfully \\
\hline Somatic and emotional states & Positive attitude/mood motivates successful performance \\
\hline
\end{tabular}

Bandura notes that self-efficacy is domain specific and can differ according to situation (1997: 42): in some circumstances people may feel more confident about their own behaviours and ability to successfully perform a task, and in others they may not. This is especially important in learning environments where access to resources varies, such as the workplace.

A further concept of relevance here - and one of the three most important to SCT alongside triadic reciprocal causation and self-efficacy - is learning orientation. Learning orientation may be understood as the mind-set that motivates the development of confidence (rather than confidence as an outcome) on the basis of existing skills, knowledge and ability. Those who exhibit learning orientation actively seek challenges and learning opportunities for the acquisition of new skills and knowledge (Bandura, 1977).
Traditionally, learning orientation has been conceived as a facet of the individual (Dweck and Leggett, 1988). However more recent research has suggested that learning orientation may also be collective (Gong, Huang and Farh, 2009) when exhibited in organisations with a commitment to learning, open-mindedness and knowledge sharing (Feng, Zhao and Su, 2013: 2902). This reflects the nature of the two types of agency understood in SCT, as discussed above.

\section{Social Cognitive Theory: applications in prior research}

As noted above, researchers working in different subject areas have used SCT. Table 2 shows examples of its application across domains other than Information Science. 
Manuscript of paper submitted to Journal of Librarianship and Information Science for publication in 2018

Table 2: Examples of the applications of Social Cognitive Theory in academic research

\begin{tabular}{|c|c|c|}
\hline Discipline & Theme & Example \\
\hline \multirow[t]{3}{*}{ Careers } & $\begin{array}{l}\text { Formation of career-related interests and } \\
\text { pursuit of educational and occupational } \\
\text { choices }\end{array}$ & Lent et al., 1994 \\
\hline & Career decision-making & Blanco, 2011 \\
\hline & Job seeking & Zikic and Saks, 2009 \\
\hline \multirow[t]{5}{*}{ Education } & E-learning & Zhang et al., 2012 \\
\hline & Self-efficacy in prisons & Allred et al., 2013 \\
\hline & Gifted education & Burney, 2008 \\
\hline & Self-efficacy and student engagement & Schunk and Mullen, 2008 \\
\hline & $\begin{array}{l}\text { Self-efficacy, health promotion, and } \\
\text { regulation of human behaviours }\end{array}$ & $\begin{array}{l}\text { Bandura, 1998; Bandura, 2004; Chapman- } \\
\text { Novakofski and Karduck, 2005; Cook et } \\
\text { al., 2015; Gordon et al., 2015; Knowlden } \\
\text { and Sharma 2012; Krebs et al., 2017; } \\
\text { Lyons et al., 2014; Rosal et al., 2014; } \\
\text { Zhang et al., } 2013\end{array}$ \\
\hline \multirow[t]{4}{*}{ Information Systems } & $\begin{array}{l}\text { Adoption of public sector electronic } \\
\text { services }\end{array}$ & $\begin{array}{l}\text { Agarwal et al., 2013; Liang and Lu, 2013; } \\
\text { Rana and Dwivedi, } 2015\end{array}$ \\
\hline & Computer training, and systems use & $\begin{array}{l}\text { Agarwal, Sambamurthy and Stair, 2000; } \\
\text { Baker et al., 2014; Bolt et al., 2001; } \\
\text { Chiang and Hsiao, 2015; Compeau and } \\
\text { Higgins, 1995; Hasan and Ali, 2006; } \\
\text { Hooper, 2012; Sherif et al., 2009; } \\
\text { Waldman, 2003; Wang et al., 2015; Yap } \\
\text { and Gaur, 2016; Yi and Davis, } 2003\end{array}$ \\
\hline & Use of the Internet and Web & $\begin{array}{l}\text { Collins et al., 2012; Hoffman et al., 2015; } \\
\text { Pearson and Pearson, } 2008\end{array}$ \\
\hline & Information security & Gulenko, 2014 \\
\hline \multirow[t]{4}{*}{ Organisational Studies } & $\begin{array}{l}\text { Improvement of levels of organisational } \\
\text { performance }\end{array}$ & Bandura, 1988 \\
\hline & Collective organisational management & Wood and Bandura, 1989 \\
\hline & Job satisfaction & Hwang et al., 2016 \\
\hline & $\begin{array}{l}\text { Self-efficacy, leadership, learning } \\
\text { orientation, and creativity }\end{array}$ & Gong et al., 2009 \\
\hline \multirow{2}{*}{$\begin{array}{l}\text { Media and } \\
\text { Communication Studies }\end{array}$} & Internet use and gratification & LaRose and Eastin, 2004 \\
\hline & $\begin{array}{l}\text { Social networks, media and mass } \\
\text { communication }\end{array}$ & Bandura, 2009 \\
\hline
\end{tabular}

SCT has been used extensively in Applied Psychology, particularly in respect of learning in different contexts (Ellis-Ormrod, 2004). Formal education settings have been most frequently explored, with an early focus on learning and the alignment of SCT with other educational models (for example, Burney, 2008). More recently educational researchers have turned their attention to self-efficacy as a key concept of SCT (for example, Schunk and Mullen, 2012). This is evident in a large number of studies that are concerned with health education: the promotion and encouragement of healthy lifestyles in general (for example, Lyons et al., 2014), and in respect of certain 
medical conditions such as cancer (Krebs et al., 2017), diabetes (Rosal et al., 2014), heart disease (Cook et al., 2015), kidney disease (Gordon et al., 2015), and obesity (Knowlden et al., 2012).

Interest in individuals in workplace environments in the Organisational Studies literature is also relatively recent. For example, in 1989 Wood and Bandura were more concerned with collective organisational management than with individuals, and it was another twenty years before the notion of self-efficacy as a mediator in the relationships between leadership, learning orientation and creativity among employees was proposed, and thus placed individuals as a central focal point of research in the workplace (Gong et al., 2009).

As well as individual studies, a number of reviews of the extant literature where SCT has been applied are available. For example, in 2008 Godin et al published a literature review on the use of SCT in studies of the behaviour of healthcare professionals. Perhaps of greater interest to Information Science researchers, however, is a literature review authored by Carillo (2010) on the deployment of SCT in the related field of Information Systems. This aligns SCT with other theoretical perspectives in the domain. The review identifies that in the 1990s SCT initially attracted the attention of Information Systems researchers interested in the concept of self-efficacy, and keen to understand behaviours around technology adoption and use (p. 21). A key consideration identified in Carillo's work is that few studies reviewed consider the emotional element emphasised by SCT (p. 27). Carillo (2010) makes explicit that the value of using SCT, however, does not lie in considering self-efficacy on its own. Rather its power is found in highlighting the complex nature of the learning processes in which self-efficacy is intertwined (p. 26), the inter-relationships of self-efficacy with cognitive, emotional, and environmental factors, and their continuous influence on one another (p. 28).

Also of interest in studies in the wider literature is the influence of SCT and its components on theory development in fields other than Psychology. For example, the concept of reciprocal determinism (i.e. interactions between social and cognitive factors of learning as determinants of behaviour) prompted Compeau and Higgins (1991) to develop a theory that takes into account individual reactions to computer technology within the environment in which learners are based, and relates these to competence development (1991: 187).

\section{Social Cognitive Theory and Information Science research}

Although SCT as applied in Information Science has not previously been the focus of a full published literature review, its relevance to the domain has been acknowledged, particularly in respect of research into information seeking behaviour and use (Case and Given, 2016: 2010; Savolinen, 2012; Wilson and Walsh, 1996). Pálsdóttir (2013), for example, argues that this theory has been valuable in investigations into motivations to seek information, to share knowledge, and to learn. The treatment of SCT in the Information Science literature as pertinent to two themes is thus elaborated below: (i) information seeking behaviour and use (including information literacy) and (ii) knowledge sharing. Examples of relevant studies are summarised in Table 3.

Table 3: Examples of the applications of Social Cognitive Theory in Information Science research

\begin{tabular}{|c|c|c|}
\hline Information Science theme & Focus & Example \\
\hline \multirow{5}{*}{$\begin{array}{l}\text { Information seeking } \\
\text { behaviour and use }\end{array}$} & Consumption of social media content & Li and Lin, 2016; Lu and Lee, 2010 \\
\hline & Information retrieval skills in academia & $\begin{array}{l}\text { Beile and Boote, 2004; Ford et al., 2001; } \\
\text { Nahl, 1993; Ren, } 2000\end{array}$ \\
\hline & $\begin{array}{l}\text { Information retrieval skills in the } \\
\text { workplace }\end{array}$ & Ren, 1999 \\
\hline & Information literacy in academia & $\begin{array}{l}\text { Kim, 2010; Kurbangolu, 2003; Lim and } \\
\text { Kwon, 2010; Pinto, 2010; Pinto, 2011; } \\
\text { Ross et al., 2016; Stokes and Urquhart, } \\
\text { 2010; Usluel, } 2007\end{array}$ \\
\hline & Everyday life information seeking & Pálsdóttir, 2008 \\
\hline \multirow[t]{2}{*}{ Knowledge sharing } & Blogging & Zakaria et al., 2013 \\
\hline & Knowledge management systems & $\begin{array}{l}\text { Dong et al., 2016; Lin and Huang, 2008; } \\
\text { Lin and Huang, } 2009\end{array}$ \\
\hline
\end{tabular}


Manuscript of paper submitted to Journal of Librarianship and Information Science for publication in 2018

\begin{tabular}{|l|l|l|}
\hline Information Science theme & Focus & Example \\
\hline \multirow{2}{*}{} & Public sector employees & $\begin{array}{l}\text { Bock and Kim 2002; Olatokun and } \\
\text { Nwafor, 2012 }\end{array}$ \\
\cline { 2 - 3 } & Wikipedians & Cho et al., 2010 \\
\cline { 2 - 3 } & Online communities & $\begin{array}{l}\text { Chui et al., 2006; Cheung et al., 2013; Kuo } \\
\text { and Young, 2008; Liou et al., 2016; } \\
\text { Olapiriyakul and Kangsirikul, 2012; Zhou, } \\
\text { 2014 }\end{array}$ \\
\hline
\end{tabular}

Typically studies of information seeking behaviour and use that deploy SCT have been conducted in educational settings with students as their data subjects, as is the case with much information seeking behaviour research (O'Brien et al., 2017, p. 248). In the earlier published work researchers wished to explain differing levels of skill in information retrieval tasks. For example, Ren (2000) found that students who had undertaken training in digital information seeking skills had higher beliefs of selfefficacy, and this contributed to an increase in search performance when they needed to search for information online. Similarly, Ford et al. (2001) found a link between low belief in self-efficacy and poor attainment amongst students presented with a task that required them to use the Internet as a source of legal information. Meanwhile Kim (2010) challenged expectations based on SCT in a student of gender differences in the use of university library website resources. Such work has often been designed with a view to determine practical interventions to raise performance, for example through training that enhances beliefs of self-efficacy (for example, Beile and Boote, 2004; Nahl, 1993).

Studies of a similar nature conducted in workplace settings are less readily identified. However, they tend to have reported findings that are comparable to those from academia. For example, Ren (1999) explored information source use of business executives and demonstrated that managers preferred to access sources, which - according to their own personal assessment - they had greatest competency in using.

Other (often more recent) work that deploys SCT in respect of research into information seeking behaviour and use is framed as information literacy research. Here, again, the theme of self-efficacy dominates the discourse. For example, Lim and Kwon (2010) uncover links between self-efficacy and information resource use with reference to gender differences; Ross et al. (2016) explore relationships between self-efficacy and information literacy in lifelong learning in a population of university students (likewise Kurbangolu (2003) in earlier work); Stokes and Urquhart (2010) profile the information literacy of nursing students according to learning style, personality and self-efficacy; and in a study of student teachers Usluel (2007) proposes that information literacy skills may develop with experience over time as belief in self-efficacy grows (p. 100). Self-efficacy has also featured as a key theme of research that has considered the consumption of health information from an everyday life information seeking perspective (Pálsdóttir, 2008).

Scales of measurement have emerged from some of these information literacy studies that draw on SCT. For example, Pinto (2010; 2011), Kurbanoglu (2003), and Kurbanoglu et al (2006) have created scales for the assessment of levels of self-efficacy to help practitioners in the delivery of information literacy programmes. A further early methodological contribution is the development of a discourse analysis technique for speech and text analysis of discussions of information practices that integrates concepts of SCT (Nahl, 2007).

It should also be noted that some output from a number of studies of information behaviour and use deploy the vocabulary of SCT, yet without explicit reference to it. For example, Tuominen et al (2005) argue that information literacy may be regarded as a social practice that is influenced by the environment (particularly the information environment), and emphasise the interplay between information technologies, workplace learning and knowledge formation processes as important to its development. Similarly, Zhang et al (2010) refine a model that takes into account the influence of information literacy skills on environmental scanning activities in the workplace. This work makes reference to self-efficacy ( $p$. 729), but not to SCT per se. More recently Hassell and Sukalich (2016) have cited the work of Bandura and commented on self-efficacy in social media use without mentioning SCT.

In respect of studies of knowledge sharing, with some exceptions (for example, Bock and Kim, 2002; Olatokun and Nwafor, 2012), most of the research on this theme that incorporates SCT tends to focus on practice in online environments (for example, Cheung et al., 2013; Chiu et al., 2006; Cho et al., 2010; Kuo and Young, 2008; Liou et al., 2016; Zakaria et al., 2013; Zhou, 2014), often with the purpose of identifying motivational factors (as noted by Oh and Syn, 2015). In common with the published work on information seeking behaviour and use, it is the concept of self-efficacy that merits most discussion in such studies. For example, Bock and Kim (2002) argue that public sector managers' self-efficacy motivates knowledge sharing, and this also contributes to organisational performance; Cho et al (2010) identified that those with higher knowledge self-efficacy are more 
likely to share knowledge within an online community; Chiu et al (2006) found that outcome expectations, i.e. the belief that certain tasks will be accomplished with a certain outcome, influence both the quality and quantity of knowledge shared; Kuo and Young (2008) observed a link between self-efficacy and knowledge sharing amongst teachers who participate in virtual online communities; and Olatokun and Nwafor (2012) found that knowledge self-efficacy was a strong determinant of knowledge sharing practice (alongside enjoyment in helping others).

As well as providing an underpinning theoretical framework for studies in Information Science such as the examples cited above, SCT has contributed to theory development within the field. Savolainen (2012: 507-508), for example, emphasises the role of self-efficacy in studies of information seeking behaviour and use, and highlights that SCT is valuable in the renewal of theory on information behaviour because it can help bridge the gap between psychological and Information Science perspectives on the same phenomena. As illustration, drew upon the concept of self-efficacy in his model of network competence (Savolainen, 2002). Similarly, Wilson and Walsh cited Bandura $(1977 ; 1986)$ using the concept of self-efficacy in the presentation of their revised general model of information behaviour of 1986, and Ford (2004) refers to the influence of mental states on information seeking and makes direct reference to self-efficacy in his proposal for a model of learning-related information behaviour. That SCT can be deployed to catalyse theory development in another domain in such ways strengthens the case for its deployment in further studies, such as that outlined below.

\section{Social Cognitive Theory and Information Science research on workplace learning and innovative work behaviour}

The identification of a suitable theoretical framework is a key question to address when designing research studies that draw upon a range of disciplines. Such a framework needs to be applicable to the main themes of the study, and also offer the flexibility to cope with the inherent interdisciplinarity of the project themes. For example, in the specific case of Information Science research discussed here - on workplace learning and innovative work behaviour - prior research in the domain of Organisational Studies needs to be considered, especially in respect of the factors that encourage the development of innovative work behaviour. These include: training (Mamaqi, 2015, p.82); appealing work spaces (Oksanen and Ståhle, 2013, p.815); supportive leaders who exhibit desired behaviours (Ellinger and Cseh, 2007); and the provision of suitable infrastructure, such as access to digital tools (Ferincz and Hortoványi, 2014).

Initial consideration of existing theoretical frameworks in Information Science for a study of workplace learning and the set of behaviours that relate to the intentional generation of new ideas within a role, group or organisation (Battistelli, Montani and Odardi, 2013:27)), proved that none were suitable. It was established, however, through the review of the literature presented in summary above, that SCT has proved a valuable tool in studies that focus on learning, and this includes prior work that has been conducted in the domain of Information Science. There are also precedents for adopting such a theory in a study of workplace learning and innovative work behaviour from an Information Science perspective. This evidence pointed to the value of adopting SCT in the current research. In addition, that SCT has previously proved successful in prompting theory development in Information Science, strengthens the case for its adoption, not least because an anticipated outcome of the study is the development of a framework that explains how workplace learning can support innovative work behaviour development within organisations.

As well as this framework, the study is anticipated to make contributions to the understanding of (i) workplace information literacy; (ii) aspects of knowledge management; and (iii) the relationship between information behaviours and innovation processes. Each of these is elaborated below.

Information literacy has previously been researched within the context of employment and employability (for example, Crawford and Irving, 2009; Crawford and Irving, 2012; Hepworth et al., 2009; Lloyd, 2011). An emphasis on the cultural elements of information literacy, as well as the development of skills and abilities relating to organisational information management, including information and knowledge sharing, resonate with the themes of the research reported in this paper. However, yet to be researched is the extent to which the development of information literacy in the workplace might be considered a factor that underpins innovative work behaviour. In addition, there tends to be a focus in this body of literature on preparing students for employment, rather than consideration of the information literacy of those already in work.

The knowledge management literature can contribute to an understanding of the themes of this research in respect of its contributions on the processes of learning at the level of the collective. Therefore aspects of organisational learning, (i.e. the creation, retention and effectively use of knowledge within organisations (Cacciattolo, 2015; Detlor et al., 2006: 117; Za et al., 2014)), are of relevance to this study. However, as is the case with other work in Information Science, the extent to which links between organisational learning and innovative work behaviour exist (or not) are yet to be investigated and made explicit. This represents a further research opportunity in the current study.

The relationship between innovation per se and other broader themes of relevance to the current study have previously been considered from an Information Science perspective. For example, there exists published research in Information Science on: workplace learning and 
innovation (Leong and Anderson, 2012); knowledge management and innovation (Rasmussen and Hall, 2016); and organisational culture and innovation (Auernhammer and Hall, 2014). Equally the relationship between information behaviour and innovation has been explored elsewhere (for example, Hauschildt, 1996). However, this prior work does not take heed of the specific theme of development of innovative behaviour in the workplace. Rather it tends to focus on other issues, such as creativity processes. As such it does not reflect all four innovation processes as detailed by Battisteli et al (2013) in their definition of innovative work behaviour, viz (i) recognition of the need for innovation, (ii) creation of an idea, (iii) championing of the idea or gaining support for the idea and (iv) idea implementation. The adoption of SCT as the theoretical framework for this study will allow for these themes, which have been neglected to date, to come to the fore.

It is anticipated that the current study on workplace learning and innovative work behaviour described may accrue some of the general benefits of (i) integrating knowledge and methods from different disciplines and (ii) using a real synthesis of approaches in the research. One of these benefits, for example, is that SCT can allow the research to address the complexities associated with producing theoretical perspectives that have wide external application and impact. (Other benefits, which may also be prompted in this study, include the debate of existing disciplinary boundaries (Zahra and Newey, 2009)). More specifically, the adoption of SCT in this study will be of value in filling gaps in knowledge related to (i) the means by which individuals and collectives develop capabilities to innovate; (ii) the environmental factors that support or hinder the development of innovative work behaviour, such as organisational culture and strategy; and (iii) how relationships between workplace learning and innovation differ according to organisational context. This will contribute to the development of a framework for the enhancement of innovation capability within the workplace.

This research will also make a contribution to the body of work on SCT itself through consideration of learning processes in multiple contexts. It will address the criticisms of prior studies that have tended to take for granted the complexity of learning (such as those identified by Carillo, 2010), with scant reference to triadic reciprocal causation and learning orientation, at the expense of a strong focus on the concept of self-efficacy. For example, by taking advantage of SCT's treatment of individuals as (i) independent agents and (ii) in collectives, elements of individual learning (workplace learning) and collective learning (organisational learning) will become apparent within this single research project. Similarly, the application of the concept of learning orientation will draw attention to the factors that influence the processes of learning necessary for the development of innovative work behaviour, such as knowledge sharing practice (rather than whether or not any specific learning outcome is achieved). Of further value is that this study focuses on learning in the workplace environment, unlike many previous studies which have been biased towards recruiting students as data subjects. This work responds to a recent call in the Information Science literature that 'More [information behaviour] research should be undertaken with... specialized populations operating in specific contexts, e.g. the workplace' (O'Brien et al., 2017, p. 251) - as opposed to with university students.

\section{Conclusion}

To date SCT has underpinned a number of studies that take an Information Science perspective, notably on themes related to information seeking behaviour and use and knowledge sharing. Through an analysis of this body of work, the practical value of SCT in Information Science research in general has been highlighted. In addition, the analysis has revealed the potential for theory development in a study on employee-led workplace learning and innovative work behaviour, anticipated to create new insight in three areas of interest to the Information Science research community: (i) workplace information literacy; (ii) knowledge management; and (iii) the relationship between information behaviours and innovation processes. As well as adding to the body of knowledge of Information Science, this first piece of academic research to apply SCT to encompass organisational and individual influences on workplace learning, will extend understandings of the application of SCT as a valuable tool for theory development across a range of domains that focus on learning processes.

\section{Declaration of Conflicting Interests}

The author(s) declared no potential conflicts of interest with respect to the research, authorship, and/or publication of this article.

\section{Funding statement}

This work was supported by an Economic and Social Research Council [grant number: ES/J500136/1] and Skills Development Scotland as part of a collaborative +3 year PhD studentship.

\section{References}

Agarwal R, Anderson C, Zarate J and Ward C (2013) If we offer it, will they accept it? Factors affecting patient use intentions of personal health records and secure messaging. Journal of Medical Internet Research 15(2): 1414.

Agarwal R, Sambamurthy V and Stair RM (2000) Research report: The evolving relationship between general and specific computer self-efficacy: An empirical assessment. Information Systems Research 11(4): 418-430. 
Allred SL, Harrison LD and O'Connell DJ (2013) Self-efficacy: An important aspect of prison-based learning. The Prison Journal 93(2): 211-233.

Auernhammer J and Hall H (2014) Organizational culture in knowledge creation, creativity and innovation: towards the Freiraum model. Journal of Information Science 40(2): 154-166.

Baker EW, Thatcher JB, Gundlach MJ and Harrison McKnight D (2014) The influence of social aversion and institutionbased trust on computer self-efficacy, computer anxiety and antecedents to IT use. Journal of Organizational Computing 26(1): 1-26.

Bandura A (1971) Social Learning Theory. New York: General Learning Press.

Bandura A (1977) Self-efficacy: Toward a unifying theory of behavioural change. Psychological Review 84(2): 191-215.

Bandura A (1986) Social Foundations of Thought and Action: A Social Cognitive Theory. Englewood Cliffs, NJ: Prentice Hall.

Bandura A (1988) Organisational application of Social Cognitive Theory. Australian Journal of Management 13(2): 275-302.

Bandura A (1989) Human agency in Social Cognitive Theory. American Psychologist 44(9): 1175-1184.

Bandura A (1998) Health promotion from the perspective of Social Cognitive Theory. Psychology and Health 13(4): 623-649.

Bandura A (2000) Exercise of human agency through collective efficacy. Current Directions in Psychological Science 9(3): 75-78.

Bandura A (2001) Social cognitive theory of mass communication. Media Psychology 3(3): 265- 299.

Bandura A (2004) Health promotion by social cognitive means. Health Education \& Behaviour 31(2): 143-164.

Bandura A (2009) Social Cognitive Theory of mass communication. Media Psychology 3(3): 264-299.

Battistelli A, Montani F and Odoardi C (2013) The impact of feedback from job and task autonomy in the relationship between dispositional resistance to change and innovative work behaviour. European Journal of Work and Organizational Psychology 22(1): 26-41.

Beile P and Boote D (2004) Does the medium matter?: A comparison of a web-based tutorial with face-to-face library instruction on education students' self-efficacy levels and learning outcomes. Research Strategies 20(1/2): 57-68.
Blanco A (2011) Applying Social Cognitive Career Theory to predict interests and choice goals in statistics in Spanish psychology students. Journal of Vocational Behaviour 78(1): 49-58.

Bock GW and Kim Y-G (2002) Breaking the myths of rewards: An exploratory study of attitudes about knowledge sharing. Information Resources Management Journal 15(2): 14-21.

Bolt MA, Killough LN and Koh HC (2001) Testing the interaction effect of task complexity in computer training using Social Cognitive Model. Decision Sciences 32(1): 120.

Burney VH (2008) Applications of Social Cognitive Theory to gifted education. Roeper Review 30(2): 130-139.

Cacciattolo K (2015) Defining workplace learning. European Scientific Journal Special Edition (1): 243-250.

Carillo KD (2010) Social Cognitive Theory in IS research literature review, criticism, and research agenda. In Proceedings of the 4th International Conference, ICISTM 2010: Information Systems, Technology and Management (ed SK Prasad, HM Vin, S Shani, MP Jaiswal and B Thipakton), Bangkok, Thailand, 11-13 March 2010, pp.2031. Germany: Springer.

Case DO and Given LM (2016) Looking for Information: A survey of research on information seeking, needs and behaviour ( $4^{\text {th }}$ ed.). Bingley, UK: Emerald Group Publishing Ltd.

Chiang H-S and Hsiao K-L (2015) YouTube stickiness: the needs, personal, and environmental perspective. Internet Research 25(1): 85-106.

Chapman-Novakofski K and Karduck J (2005) Improvement in knowledge, Social Cognitive Theory variables and movement through stages of change after a community based diabetes education program. Journal of American Dietetic Association 105(10), 1613-1616.

Cheung MKC, Lee MKO and Lee ZWY (2013) Understanding the continuance intention of knowledge sharing in online communities of practice through the post-knowledgesharing evaluation process. Journal of the Association for Information Science and Technology 64(7): 1357-1374.

Chiu C-M, Hsu M-H and Wang ETG (2006) Understanding knowledge sharing in virtual communities: An integration of social capital and social cognitive theories. Decision Support Systems 42: 1872-1888.

Cho H, Chen M and Chung S (2010) Testing an integrative theoretical model of knowledge-sharing behavior in the 
Manuscript of paper submitted to Journal of Librarianship and Information Science for publication in 2018

context of Wikipedia. Journal of the Association for Information Science and Technology 61(6): 1198-1212.

Collins CE, Morgan PJ, Fletcher K, Martin J, Aguiar EJ, Lucas A, Neve M and Callister R (2012) A 12 week commercial web-based weight-loss program for overweight and obese adults: randomized control trial comparing basic versus enhanced features. Journal of Medical Research 14(2): $1-1$

Compeau DR and Higgins CA (1995) Application of Social Cognitive Theory to training for computer skills. Information Systems Research 6(2): 118-143.

Cook RF, Hersch R, Schlossberg D and Leaf SL (2015) A webbased health promotion program for older workers: randomized control trial. Journal of Medical Internet Research 17(3): 1-1.

Crawford J and Irving R (2012) Information literacy in employability: the experience of Inverclyde Libraries. Journal of Librarianship and Information Science 44(2): 79-89.

Crawford J and Irving C (2009) Information literacy in the workplace: a qualitative exploratory study. Journal of Librarianship and Information Science 41(1): 29-38.

Detlor B, Ruhi U, Turel O, Bergeron P, Choo C W, Heaton L and Paquette S (2006) Effect of knowledge management context on knowledge management practices: An empirical investigation. Electronic Journal of Knowledge Management 4(2): 117-128.

Dong T-P, Hung C-L and Cheng N-C (2016) Enhancing knowledge sharing intention through satisfactory context of continual service of knowledge management systems. Information Technology \& People 29(4): 807-829.

Dweck CS and Leggett EL (1988) A Social-Cognitive approach to motivation and personality. Psychological Review 95(2): 256-273.

Ellinger AD and Cseh M (2007) Contextual factors influencing the facilitation of others' learning through everyday work experiences. Journal of Workplace Learning 19(7) 435452.

Ellis-Ormrod J (2004) Human Learning. Upper Saddle River, N.J: Prentice Hall.

Feng T, Zhao G and Su K (2013) The fit between environmental management systems in organisational learning orientation. International Journal of Production Research 52(10): 2901-2914.

Ferincz A Hortoványi L (2014) Beyond human-computer collaboration: Supporting and hindering factors of on-the- job learning. In $6^{\text {th }}$ International Conference An Enterprise Odyssey: Corporate Governance and Public Policy - Path to Sustainable Future (ed L Galetić and J Šimurina), Šibenik, Croatia, 13-16 June 2012, pp.847-868. Zagreb: Faculty of Economics and Business.

Ford N (2004) Towards a model of learning for educational informatics. Journal of Documentation 60(2): 183-225.

Ford N, Miller D and Moss N (2001) The role of individual differences in Internet searching: An empirical study. Journal of the American Society for Information Science and Technology 52(12): 1049-1066.

Godin G, Bélanger-Grave A, Eccles M and Grimshaw J (2008) Healthcare professionals' intentions and behaviour: A systematic review of studies based on social cognitive theories. Implementation Science 3(36): 1-12.

Gong Y, Huang J-C and Farh J-L (2009) Employee learning orientation, transformational leadership, and employee creativity: the mediating role of creative self-efficacy. Academy of Management Journal 52(4): 765-778.

Gordon EJ, Feinglass J, Carney P, Ramirez D, Olivero M, O'Connor K, MacLean K, Brucker J and Caicedo JC (2015) An interactive, bilingual, culturally targeted website about living with kidney donation and transplantation for Hispanic: development and formative evaluation. Journal of Medical Internet Research 17(5): 1-1.

Gulenko I (2014) Improving passwords: influence of emotions on security behavior. Information Management \& Computer Security 22(2): 167-178.

Hall H (2003) Borrowed theory: applying exchange theories in information science research. Library and Information Science Research, 25(3): 287-306.

Hasan B and Ali JH (2006) The impact of general and systemspecific self-efficacy on computer training learning and reactions. Academy of Information and Management Sciences Journal 9(1), 17-35.

Hassell M and Sukalich (2016) A deeper look into the complex relationship between social media use and academic outcomes and attitudes. Information Research 21(4).

Hauschildt J (1996) Innovation, creativity and information behaviour. Creativity and Innovation Management 5(3): 169-178.

Hepworth M, Walton G and Almehmadi F (2013) Introduction - information literacy and information behaviour, complementary approaches for building capability. In: Hepworth M and Walton G (eds) Developing people's information capabilities: fostering information literacy in 
educational, workplace and community contexts. Bingley, UK: Emerald Publishing, pp. 1-10.

Hoffman CP, Lutz C and Meckel M (2015) Content creation on the Internet: a social cognitive perspective on the participation divide. Information, Communication \& Society 18(6): 696-716.

Hooper V (2012) What is and what is not acceptable behavior on social networking sites: a study of youth on Facebook. In Proceedings of the $3^{\text {rd }}$ International Conference on Information Management \& Evaluation: ICIME2012 (ed TE Erkan), Ankara, Turkey, 16-17 April 2012, pp.121-128. Reading, UK: Academic Conferences Ltd.

Hwang Y, Lee Y and Shin D-H (2016) The role of goal awareness and information technology self-efficacy on job satisfaction of healthcare system users. Behaviour \& Information Technology 35(7): 548-558.

Kim Y-M (2010) Gender role and the use of university library website resources: A Social Cognitive Theory perspective. Journal of Information Science 36(5): 603-617.

Knowlden A and Sharma M (2012) A feasibility and efficacy randomized control trial of online prevention program for childhood obesity: protocol for the EMPOWER intervention. Journal of Medical Internet Research 14(3): 3-3.

Krebs P, Shtaynberger J, McCabe M, Iocolano M, Williams K, Shuk E, Ostroff JS and Eddens K (2017) An eHealth intervention to increase physical activity and healthy eating in older adult cancer survivors: summative evaluation results. Journal of Medical Internet Research 19(3): 1-1.

Kuo F-Y and Young M-L (2008) A study of the intention-action gap in knowledge sharing practices. Journal of the American Society for Information Science and Technology 59(8): 1224-1237.

Kurbanoglu SS (2003) Self-efficacy: a concept closely linked to information literacy and lifelong learning. Journal of Documentation 59(6): 635-646.

Kurbanoglu SS Akkoyunlu B and Umay A (2006) Developing the information literacy self-efficacy scale. Journal of Documentation 62(6): 730-743.

LaRose R and Eastin MS (2004) A Social Cognitive Theory of internet use and gratification: Toward a new model of media attendance. Journal of Broadcasting \& Electronic Media 48(3): 358-377.

Lent RW, Brown SD and Hackett G (1994) Toward a unifying Social Cognitive Theory of career and academic interest, choice and performance. Journal of Vocational Behaviour 45(1): 79-122.

Leong J and Anderson C (2012) Fostering innovation through cultural change. Library Management 33(8/9): 490-497.

Li L and Lin TTC (2016) Examining Weibo posting anxiety among well-educated youth in China. Information Development 32(4): 1240-1252.

Liang S-W and Lu H-P (2013) Adoption of e-government services: an empirical study of the online tax filing system in Taiwan. Online Information Review 37(3): 424-444.

Lim S and Kwon N (2010) Gender differences in information behavior concerning Wikipedia, and unorthodox information source? Library and Information Science Research 32(3): 212-220.

Lin C-T and Huang C-C (2008) Understanding knowledge management system usage antecedents: An integration of social cognitive theory and task technology fit. Information \& Management 45(6): 410-417.

Lin C-T and Huang C-C (2009) Understanding the determinants of EKR usage from social, technological and personal perspectives. Journal of Information Science 35(2): 165-179.

Liou D-K, Chih W-H, Yuan C-Y and Lin C-Y (2016). The study of the antecedents of knowledge sharing behavior. Internet Research 26(4): 845-868.

Lloyd A (2011) Trapped between a rock and a hard place: what counts as information literacy in the workplace and how is it conceptualized? Library Trends 60(2): 277-296.

Lu H-P and Lee M-R (2010) Demographic differences and the antecedents of blog stickiness. Online Information Review 34(1): 21-38.

Lyons E, Lewis ZH, Marysron BG and Rowland JL (2014) Behaviour change techniques implemented in electronic lifestyle activity monitors: a systematic content analysis. Journal of Medical Internet Research 16(8): 1-1.

Mamaqi X (2015) The efficiency of different ways of informal learning on firm performance: A comparison between, classroom, web 2 and workplace training. Computers in Human Behavior 51: 812-820. http://doi.org/10.1016/j.chb.2014.11.080

Nahl D (1993) CD-ROM point-of-use instructions for novice searchers: a comparison of user- centered affectively elaborated and system-centered unelaborated text. $\mathrm{PhD}$ Thesis, University of Hawaii, Honolulu, Hawaii, USA. Available at: http://www2.hawaii.edu/ nahl/articles/phd/phd1to3. 
Manuscript of paper submitted to Journal of Librarianship and Information Science for publication in 2018

html (Archived by WebCiteR at http://www.webcitation.org/6BGbvqylW) (accessed 24 July 2016)

Nahl D (2007) A discourse analysis technique for charting the flow of micro-information behavior. Journal of Documentation 63(3): 323-339.

O’Brien, H, Dickinson R and Askin N (2017) A scoping review of individual differences in information seeking behavior and retrieval research between 2000 and 2015. Library and Information Science Research 39 244-254. http://dx.doi.org/10.1016/i.lisr.2017.07.007

Oh S and Syn SY (2015) Motivations for sharing knowledge and social support in social media: a comparative analysis of Facebook, Twitter, Delicious, YouTube, and Flickr. Journal of the Association for Information Science and Technology 66(10): 2045-2060.

Oksanen K and Ståhle P (2013) Physical environment as a source for innovation: investigating the attributes of innovative space. Journal of Knowledge Management 17(6): 815-827. http://doi.org/10.1108/JKM-04-2013$\underline{0136}$

Olapiriyakul K and Kangsirikul S (2012) The role of webforum in knowledge sharing and its impacts on consumer's purchase intention in e-marketplaces. International Journal of Innovation \& Learning 12(3): 283293.

Olatokun W and Nwafor CI (2012) The effect of extrinsic and intrinsic motivation on knowledge sharing intentions of civil servants in Ebonyi State, Nigeria. Information Development 28(3)216-234.

Pálsdóttir A (2008) Information behaviour, health self-efficacy beliefs and health behaviours in Icelanders' everyday life. Information Research 13(1).

Pálsdóttir A (2013) Social cognitive theory. In Wilson TD (eds). Theory in Information Behaviour research. Sheffield, UK: Eiconics Ltd. [E-book] ISBN 978-0-9574957-0-8.

Pearson MJ and Pearson, AM (2008) An exploratory study into determining the relative importance of key criteria approach The Journal of Computer Information Systems 48(4): 115-127.

Pinto M (2010) Design of the IL-HUMASS survey on information literacy in higher education: A selfassessment approach. Journal of Information Science 36(1): 86-103.
Pinto M (2011) An approach to the internal facet of information literacy using the ILHUMASS survey. Journal of Academic Librarianship 37(2): 145-154.

Rana NP and Dwivedi YK (2015) Citizen's adoption of an egovernment system: validating extended social cognitive theory (SCT). Government Information Quarterly 32(2): 172-181.

Rasmussen L and Hall H (2016) The adoption process in management innovation: a knowledge management case study. Journal of Information Science 42(3): 356-368.

Ren W-H (1999) Self-efficacy and the search for government information. Reference \& User Service Quarterly 38(3): 283-291.

Ren W-H (2000) Library instruction and college student selfefficacy in electronic information searching. Journal of Academic Librarianship 26(5): 323-328.

Rijsford M (2009) Nursing Knowledge: Science, Practice, and Philosophy. Wiley-Blackwell.

Rosal M, Heyden R, Mejilla R, Capelson R, Chalmers KA, DePaoli MR, Veerappa C and Wiecha JM (2014) A virtual world versus face-to-face intervention format to promote diabetes self-management among African American women: a polio randomized clinical trial. Journal of Medical Internet Research 16(10): 1-1.

Ross M, Perkins H and Bodey K (2016) Academic motivation and information literacy self-efficacy: the importance of the simple desire to know. Library and Information Science Research 38(1): 2-9.

Savolainen R (2002) Network competence and information seeking on the internet: From definitions towards a social cognitive model. Journal of Documentation 58(2): 211226.

Savolainen R (2012) Expectancy-value beliefs and information needs as motivators for task-based information seeking. Journal of Documentation 68(4) 492511.

Schunk DH and Mullen CA(2012) Self-efficacy as an engaged learner. In Christenson SL, Reschly AL and Wylie C (eds). Handbook of Research on Student Engagement. New York, NY: Springer, pp. 219-235.

Sherif K, Song J and Wilcox J (2009) A social status perspective of network utility over electronic channels in academic countries. International Journal of Information Management 29(4): 262-271. 
Stokes P and Urquhart C (2010) Profiling information behaviour of nursing students: part 1: quantitative findings. Journal of Documentation 67(6): 908-932.

Treux D, Holström J and Keil M (2006) Theorizing in information systems research: A reflexive analysis of the adaptation of theory in information systems research. Journal of the Association for Information Systems 7(12): 797-821.

Tuominen K, Savolainen R and Talja S (2005) Information literacy as a sociotechnical practice1. The Library Quarterly: Information, Community, Policy 75(3): 329-345.

Usluel YK (2007) Can ICT usage make a difference on student teachers' information literacy self-efficacy. Library \& Information Science Research 29(1): 92- 102.

Waldman M (2003) Freshmen's use of library electronic resources and self-efficacy. Information Research 8(2): 130.

Wang D, Xu L and Chan H-C (2015) Understanding the continuance use of social network sites: a computer selfefficacy perspective. Behaviour \& Information Technology 34(2): 204-216.

Whetten DA, Felin T and King BG (2009) The practice of borrowing in organizational studies: Current issues and future directions. Journal of Management 35(5): 537-563.

Wilson T D and Walsh C (1996) Information behaviour: An interdisciplinary perspective. Sheffield: University of Sheffield Department of Information Studies. Available at: http://informationr.net/tdw/publ/infbehav/cont.html (Archived by WebCiteR at http://www.webcitation.org/6BGeZER3i) (accessed 24 July 2016)

Wood R and Bandura A (1989) Social Cognitive Theory of organisational management. Academy of Management Review 14(3): 361-384.

Yap S-F and Gaur SS (2016) Integrating functional, social and psychological determinants to explain online social networking usage. Behaviour \& Information Technology 35(3): 166-183.

Yi M-Y and Davis FD (2003) Developing and validating an observational learning model of computer software training and skill acquisition. Information Systems Research 14(2): 146-169.

Za S, Spagnoletti P and North-Samardzic A (2014) Organisational learning as an emerging process: The generative role of digital tools in informal learning practices. British Journal of Educational Technology 45(6): 1023-1035. http://doi.org/10.1111/bjet.12211

Zakaria R, Saniah Sulaiman, NI, Ibrahim H, Syazwan A and Zura Zabidi N (2013). The role of individual factor in knowledge sharing behavior among profit orientated webloggers. Proceedings of the $14^{\text {th }}$ European Conference on Knowledge Management 2:961-967.

Zahra SA and Newey LR (2009) Maximising the impact of organizational science theory building and the intersection of disciplines and / or field. Journal of Management Studies 46(6): 1059-1075.

Zhang N, Campoo S, Janz KF, Eckler P, Jungzhen Y, Snetselaar LG and Signorini A (2013) Electronic word of mouth on Twitter about physical activity in the United States: exploratory infodemiology study. Journal of Medical Internet Research 15(11): 13-13.

Zhang Y, Fang Y, Wei K-K and Wang Z (2012) Promoting the intention of students to continue their participation in elearning systems: the role of the communication environment. Information Technology \& People 25(4): 356-375.

Zhang X, Majid S and Foo S (2010) Environmental scanning: An application of information literacy skills at the workplace. Journal of Information Science 36(6): 719-732.

Zhou (2014) How fundamental and supplemental interactions affect users' knowledge sharing in virtual communities? A social cognitive perspective. Internet Research 24(5): 1-23.

Zikic J and Saks AM (2009) Jobsearch and Social Cognitive Theory: The role of career-related activities. Journal of Vocational Behaviour 74(1): 117-127. 